\title{
Modernin demokratian juuria etsimässä
}

\author{
Jermu Laine (1999) \\ Alexis de Tocqueville, \\ demokratian ja vapau- \\ den moderni yhteen- \\ sovittaja. Helsinki: \\ EDITA
}

Euroopan Unionin jäsenyys merkitsi kansallisen suvereniteettimme kaventumista. Vaikka oma eduskuntamme on merkittävästi vahvemmin mukana EU-asioiden valmistelussa kuin muiden jäsenmaiden parlamentit, huoli kansanvallan kaventumisesta ja demokratiavajeesta on perusteltu. Samaan aikaan EU-jäsenyyden kanssa toteutimme varsin radikaalin päätösvallan hajautuksen ja vastuu peruspalveluista siirrettiin kunnille. Tämän arveltiin lisäävän kansalaisten kiinnostusta kunnalliseen demokratiaan, mutta toisin kävi. Vuoden 2000 kunnallisvaalien äänestysaktiviteetti oli ennätyksellisen alhainen. Jonot ostoskeskusten vaalimökeillä olivat lyhyet ja tv-kanavien pintaliitoa huristavat vaaliohjelmat eivät jaksaneet kiinnostaa enää edes mukana olevia puhuvia päitä.

\section{Uusliberalistinen yhteis-} kuntapolitiikka sallii tuloerojen kasvun, pitää sitä jopa menestyvän talous- ja yhteiskuntapolitiikan edellytyksenä. Kansalaiset ihmettelevät, mihin taloudellisen kasvun tulokset oikein häipyvät. Missä on nyt se yhteisvastuu, jonka varaan pohjoismainen hyvinvointiyhteiskunta rakentui? Nouseeko käräjäoikeus köy- hän parhaaksi ystäväksi, jonka kautta on perättävä lain turvaamia oikeuksia?

Kyllästyminen puoluepolitiikkaan on tosiasia ja varsinkin nuorempi väki hakee uusia, suorempia vaikutuskanavia. Ovatko uudet vaikuttamisen mahdollisuudet paikallisella ja alueellisella tasolla aidosti kasvamassa ja miten niihin suhtautuu perinteinen poliittisten puolueiden varaan rakentuva järjestelmä? Entä mikä on paikallisen ja alueellisen vaikuttamisen suhde kansalliseen ja eurooppalaiseen keskusvaltaan, jos ja kun EU kehittyy kohti liittovaltiota?

\section{Kaikilla näillä yhteis-} kunnallisilla ilmiöillä ja meneillään olevalla pohdiskelulla on yhteinen nimittäjä. Kyse on demokratian, kansansuvereniteetin toteutumisesta ja erityisesti tasa-arvon edellyttämän vastuun ja demokratiaan kuuluvan vapauden suhteesta. Olemme siinä määrin perimmäisten kysymysten äärellä, että muun ohella on mielenkiintoista, jopa tarpeen tutustua länsimaisen demokratian juuriin. Siihen tarjoaa oivan mahdollisuuden Jermu Laineen kirja Alexis de Tocquevillestä.

\section{Alexis de Tocqueville} syntyi vuonna 1805 Pariisissa. Hänen vanhempansa kreivi Hervé de Tocqueville ja Luise-Madeleine Rosanbond joutuivat vuonna 1803 vallankumouksellisten pidättämiksi ja vain Robespierren joutuminen giljotiiniin pelas- ti heidät mestaukselta. Kuningasvallan palattua isä sai viran maakuntahallinnosta. Alexis opiskeli lakia ja pääsi töihin Kaarle X:n hallintoon. Kevät 1831 oli käänteentekevä nuoren miehen elämässä.

\section{Hän sai hallitukselta} tehtäväksi lähteä ystävänsä Gustave de Beamontin kanssa tutustumaan Yhdysvaltojen vankilaoloihin. Vajaan vuoden opinto- ja tutkimusmatka tuotti hallitukselle sen toivoman raportin, mutta Tocquevillen varsinainen kiinnostuksen kohde ei ollut vankeinhoito, vaan demokratia. Hän halusi nähdä, miten amerikkalainen demokratia toimi käytännössä ja olisiko uuden mantereen kokemuksista jotakin opittavaa Euroopassa. Hän sai, mitä halusi ja kirjoitti kokemuksistaan kirjan Amerikandemokratia(DelaD'emocratie en Am 'èrique). Sen ensimmäinen laitos ilmestyi vuonna 1835 ja toinen 1840.

\section{Kirja oli menestys.}

Se käännettiin mm. englanniksi, saksaksi ja ruotsiksi. Suomeksi kirjaa ei ole käännetty, kuten ei muitakaan Tocquevillen teoksia. Tästä syystä Jermu Laineen Tocquevillen keskeisiä ajatuksia esittelevä kirja on todella tervetullut puheenvuoro kansalliseen demokratia-keskusteluumme. Kirjan ytimen muodostavat Tocquevillen ajatukset, jotka Laine tarjoilee lukijalle loogisesti ja mielenkiintoisesti jäsennettynä. Luettavuutta parantavat Laineen tekemät kytkennät suomalaiseen nykytodellisuuteen. 
Mikä tekee Tocquevillestä mielenkiintoisen? Ensinnäkin hänen kykynsä nähdä tulevaisuuteen. Vaikka hän oli itsekin mukana päivän politiikassa, hän toteaa: "Puolueet ovat kiinni huomisen murheissa, minä haluan visioida tulevaisuutta": Siinä hän onnistui. Hänen 170 vuotta sitten tekemänsä analyysi demokratian olemuksesta ennakoi hämmästyttävän hyvin myös suomalaista nykytodellisuutta.

Toiseksi hänen lähestymistapansa on hyvin pragmaattinen. Laine sijoittaa Tocquevillen traagisten historioitsijoiden joukkoon. Vaikka hän tunnustaa ristiriitojen päättymättömyyden, hän ei ole pessimisti. Hän ei ole myöskään utopisti, vaan myöntää, etteivät demokratia ja tasaarvo ratkaise yksilön ja yhteiskunnan ongelmia. Hän on sillanrakentaja vanhan ja uuden, yhtäältä väistyvän feodalismin ja aristokratian ja toisaalta demokratian välillä. Hän teki koko ajan eräänlaista kenttätutkimusta poliittisten myllerrysten keskellä elävässä Ranskassa, teollistuvassa Englannissa ja demokratiaa käytännössä toteuttavassa Amerikassa. Näin hän porautuu demokratian olemukseen ymmärrettävästi ja tuo esiin niin demokratian tarjoamat mahdollisuudet kuin siihen liittyvä uhkat. "Demokratian ystävänä minun on pakko kertoa totuus demokratiasta, pelkurit eivät sitä tee.”

\section{Tocqueville lähestyy}

demokratia-käsitettä eri näkökulmista. Tiivistäen voidaan demokratian merkitsevän hänelle yhtäältä poliittista järjestelmää, johon kuului kansasta riippuvainen hallitus, toisaalta jatkuvasti liikkeessä olevaa vallankumouksellista prosessia kohti tasa-arvoa. Siihen sisältyy toisiin kohdistuvan vallankäytön kielto, itse asiassa se tähtää ihmisten riippumattomuuteen toisistaan, jolloin se kehittyy tavallaan epäyhteiskunnalliseksi vapausideaksi. Jotta demokratia voisi luoda pohjan tasa-arvolle, tarvitaan yksilöllisyyden ja vapauden vastapainoksi yhteisyyttä vahvistavaa kansalaistoimintaa, ihmisten vuorovaikutusta, huolta yhteisistä asioista ja demokratiaan liittyvien epäterveiden lieveilmiöiden torjuntaa.

\section{Valppautta demokratian} vaalijoilta todella vaaditaankin, koska vihollinen on niin lähellä! Se on kansa itse! Kuinka helppoa onkaan olla samaa mieltä kuin yleinen mielipide tai yhtyä enemmistön näkemykseen. Tai kukapa itse asiassa hoitaisi asioitani paremmin kuin vahva keskusvalta tai tehokas korporaatio. Näin säädyistä, luokista ja ennakkoluuloista vapautunut ihminen antaa sidotuttaa itsensä modernin tyrannian ja pehmeän despotismin otteeseen. Jermu Laineen mukaan Tocquevillen koko poliittisen filosofian ydinosa on demokraattisen despotismin luonteen erittelyä ja uhkien valottamista. Tähän mielenkiintoiseen ja mitä ajankohtaisimpaan pohdiskeluun lukija pääsee mukaan Laineen erinomaisella opastuksella.

\section{Mistä sitten löytyvät}

kansalaisen kumppanit taistelussa demokratian ja tasaarvon puolesta? Vastaukseksi käykööt Tocquevilleltä lainatut otsikot: "Lehdistö - en pidä siitä, mutta se on vapau- den paras taisteluase", "Oikeuslaitos ja lakimieskunta demokratian aristokraattinen tuki”, "Kansalaisjärjestöt despotismin ja individualismin hillitsijät".

\section{Aikuiskasvattajan}

kannalta mielenkiintoinen on myös demokratian omaa ja omituista kieltä tarkasteleva luku. Tocquevillen kielenkäytöstä ja puhetaidosta saa kuvan sivuilta $31-35$, mihin on lainattu kokonaisuudessaan hänen 21.1.1848 parlamentin edustajahuoneessa pitämänsä puhe, jossa hän ruoskii hallituksen mädännäisyyttä ja ennakoi kuukauden kuluttua puhjenneen helmikuun vallankumouksen. Sitä pidetään Ranskan historian kaikkien aikojen kuuluisimpana puheena. Kirja kannattaa hankkia jo pelkästään siksi.

\section{Laineen kirjaa lukiessani} kaivoin kirjahyllystäni vuonna 1977 ilmestyneen TANDEMprojektin loppuraportin $D e$ mokratian rajatja rakenteet. Kiistelty projekti ja runtattu raportti. Kaikesta huolimatta hanke pyrki kartoittamaan sääty-yhteiskunnan purkautumisesta aiheutuneita vaikutuksia suomalaiseen hallitsemistapaan. Nyt minusta olisi aika jälleen suorittaa poikkileikkaus demokratian tilasta ja tulevaisuuden näkymistä.

Asian pitäisi kiinnostaa myös ja ehkä ennen kaikkea aikuiskasvattajia ja alan tutkijoita. Miten olisi, löytyisikö rohkeutta omistaa esimerkiksi Aikuiskasvatuksen vuosikirja demokratian tarkastelulle ja lähestyä asiaa ennen kaikkea aikuiskasvattajan näkökulmasta? Toivotaan ja uskotaan.

Erkki Aho 